\title{
Estrategias socio afectivas como método de enseñanza en tiempos de pandemia Covid-19, una forma para desarrollar destrezas productivas en el aprendizaje colaborativo
}

Socio-affective strategies as a teaching method in times of the Covid-19 pandemic, a way to develop productive skills in collaborative learning

1 Andrea Karina Carvajal Gavilanes $\quad$ (iD) https://orcid.org/0000-0002-6813-9936 Universidad Técnica de Ambato, Facultad de Ciencias Humanas y de la Educación (E), Ambato, Ecuador, acarvajal5121@uta.edu.ec

2 Rubela Jeaneth Pila López https://orcid.org/0000-0002-6159-3431 Universidad de las Fuerzas Armadas ESPE, Departamento de Ciencias Humanas y Sociales, Ambato, Ecuador rjpila@espe.edu.ec

3 Diego Santiago Andrade Naranjo $\quad$ iD https://orcid.org/0000-0002-5536-6267 Universidad de las Fuerzas Armadas ESPE, Departamento de Ciencias Humanas y Sociales, Ambato, Ecuador dsandrade3@espe.edu.ec

4 Milton Andrés Arellano Reyes $\quad$ (iD) https://orcid.org/0000-0001-8217-3834 Universidad de las Fuerzas Armadas ESPE, Departamento de Ciencias Humanas y Sociales, Ambato, Ecuador maarellano3@espe.edu.ec

Artículo de Investigación Científica y Tecnológica Enviado: 24/12/2021 Revisado: 29/12/2021 Aceptado: $12 / 01 / 2022$ Publicado:08/03/2023 DOI: https://doi.org/10.33262/concienciadigital.v6i1.4.2015

Cítese: Carvajal Gavilanes, A. K., Pila López, R. J., Andrade Naranjo , D. S., \& Arellano Reyes, M. A. (2023). Estrategias socio afectivas como método de enseñanza en tiempos de pandemia Covid-19, una forma para desarrollar destrezas productivas en el aprendizaje colaborativo.

ConcienciaDigital, $6(1.4)$ 581-592. https://doi.org/10.33262/concienciadigital.v6i1.4.2015

CONCIENCIA DIGITAL, es una Revista Multidisciplinar, Trimestral, que se publicará en soporte electrónico tiene como misión contribuir a la formación de profesionales competentes con visión humanística y crítica que sean capaces de exponer sus resultados investigativos y científicos en la misma medida que se promueva mediante su intervención cambios positivos en la sociedad. https://concienciadigital.org

La revista es editada por la Editorial Ciencia Digital (Editorial de prestigio registrada en la Cámara Ecuatoriana de Libro con No de Afiliación 663) www.celibro.org.ec 


\section{Palabras} claves:

estrategias, socioafectivo, destrezas productivas, aprendizaje, pandemia.

\section{Keywords:}

strategies, socio-affective, productive skills, learning, pandemic

\section{Resumen}

Introducción. Con el fin de establecer vínculos entre las estrategias socio-afectivas y el desarrollo de habilidades productivas en el aprendizaje colaborativo en tiempos de pandemia (covid-19), se toma como referencia el conjunto de estrategias que determinan las pautas generales a seguir para comunicarse de manera efectiva oralmente o por escrito, por lo que una sobrecarga de actividades individuales como única estrategia de comunicación conduce a tener un entorno socio-afectivo inadecuado para el desarrollo de la comunicación en la interactividad de clase más aún hoy en día por el encierro realizado por la pandemia (covid-19) que de una forma $\mathrm{u}$ otra ha limitado el uso de nuevas estrategias en el aprendizaje colaborativo. Objetivo. Determinar la incidencia que tiene las estrategias socioafectivas en el desarrollo de las destrezas productivas en el aprendizaje colaborativo en los estudiantes. Metodología. En este contexto, se propuso realizar la presente investigación con un enfoque cualitativo-cuantitativo, en el que la población y muestra estuvo conformada por 169 estudiantes y 4 profesores. La validez de la propuesta se demostró a través de técnicas e instrumentos de investigación como las encuestas. Resultados. Durante el procesamiento de la información se presentaron los resultados mediante tablas de frecuencia y porcentajes, los análisis e interpretaciones seleccionadas. Conclusión. Las estrategias socio afectivas influyen de manera permanente y positiva en el proceso de aprendizaje colaborativo en el desarrollo de habilidades productivas en tiempos de pandemia (COVID-19).

\section{Abstract}

Introduction. In order to establish links between socio-affective strategies and the development of productive skills in collaborative learning in times of pandemic (covid-19), the set of strategies that determine the general guidelines to follow to communicate in a Effectively orally or in writing, so that an overload of individual activities as the only communication strategy leads to an inappropriate socio-affective environment for the development of communication in class interactivity, even more so today due to the confinement carried out by the pandemic (covid-19) that in one way or another has limited the use of new strategies in collaborative learning. Objective. Determine the impact that socio-affective 
strategies have on the development of productive skills in collaborative learning in students. Methodology. In this context, it was proposed to carry out the present investigation with a qualitative-quantitative approach, in which the population and sample consisted of 169 students and 4 teachers. The validity of the proposal was demonstrated through research techniques and instruments such as surveys. Results. During the information processing, the results were presented using tables of frequency and percentages, the analyzes and selected interpretations. Conclusion. Socio-affective strategies permanently and positively influence the collaborative learning process in the development of productive skills in times of pandemic (COVID-19).

\section{Introduction}

One of the fundamental reasons why this research is carried out is to analyze the inadequate application of socio-affective strategies in the development of productive skills, establish causes and effects, relate them to this issue and through this promote alternatives to massif the strategies socio-affective activating them inside and outside the educational settings with the aim of obtaining a better collaborative learning result in times of the covid19 pandemic. Therefore, it is hoped that by investigating existing pedagogical problems, solutions can be provided that allow to raise the academic performance of students and provide society with graduates with the ability to solve problems and assume the reins of their own destiny.

The importance of this research work is aimed at solving problems by expressing themselves orally and in writing in a collaborative environment, which affects the educational quality in students, causing difficulties at the time of graduation, having limited learning results and poor development of the basic skills, abilities, and competencies that they should master.

Considering that teaching is a dynamic and not static exchange factor, in which all factors must be grouped for the proper development of a class, therefore a great difficulty is the limited implementation of socio-affective strategies for the development of collaborative learning and productive skills in the confinement of the covid-19 pandemic, which causes minimal participation in group work as part of academic development, since on the contrary it should become an unlimited learning that raises fruitful questions that lead to students to have an adequate collaborative communication (Rukmini \& Saputri, 2017). 
Nowadays the new teachings on the language in official schools conceptualize socioaffective strategies as those decisions that have a direct impact on the information to be learned, according to Golkova and Hubackova (2014) which improves the level of cognitive functioning of the student relating to the part emotional and thus control the feelings and attitudes of the students to relate them to learning since the behavior favorably reinforces personal and social factors.

Likewise, socio-affective strategies allow the student to motivate himself, concentrate, control emotions and attitudes, thus being an indispensable part of learning a second language. Mutia Hammed (2020) as is already known, socio-affective strategies facilitate interaction with other people involved in the learning process, these strategies allow to have a better classroom environment to help in a social and affective way group learning through cooperation and empathy with others, the fact of asking questions that often completely represses students, causing their self-esteem lower and lock them completely to be able to perform adequately in inter-learning.

Seen this way, with this type of strategies we open up new forms and processes of learning that allow interaction and mutual collaboration to achieve the objectives set in the learning cycle (Sreena and Ilankumaran, 2018). Socio-affective strategies include student-student, teacher-student cooperation, to reduce the level of anxiety and stress when communicating, since it is true that between students, they feel freer when talking between peers but when they have to do it in another language their knowledge is blocked causing them to limit the activity when expressing themselves.

It should be emphasized that in the same way, the development of productive skills is a fundamental part of learning since these are an indispensable part in the individual progress of student as Liu Yan (2020) mentions that a reduced use of activities that generate the effective progress of the skills in the classroom, which due to confinement due to pandemic (Covid-19) have the effect of using monotonous activities, hindering active communicative production, the student cannot fully demonstrate the skills acquired since monotony prevents it from developing a more participatory and collaborative language that allows them to function autonomously.

Robiansyah and Rochmahwati (2020) indicates that when we talk about activities that take place in a master class when there is confinement due to pandemic, individual and group participation must be taken into account, it is essential to acquire extra material that serves as reinforcement and support in the development of productive skills since practice and performance allow greater security when expressing ourselves, therefore a scant updated supplementary material gives us an idea contrary to the aforementioned, having as a negative effect a restricted application of productive skills in the educational process. 


\section{Methodology}

According to Herrera et al. (2010) "it is predominantly qualitative research when it is naturalistic, participatory, ethnographic, humanistic, internal, and interpretive. It is predominantly quantitative research when it is normative, nomothetic, external, explanatory, and realistic. The focus of this research is eminently qualitative-quantitative (Monereo et al., 2007). Qualitative because in the first place it interprets, analyzes, and seeks the understanding of the facts, the problematic situation, studying the importance from those involved; on socio-affective strategies in the development of productive skills in collaborative learning in times of pandemic. Quantitative because numerical data will be obtained, applying statistical processes that allowed to verify, demonstrate results for the proposed hypothesis.

To collect the necessary information about the problem, the specific instruments of each of the collection techniques were applied, which are: observation, interview, survey

An observation sheet was prepared, which was applied to third-year high school students, and teachers, during the class time that the teacher was developing, and it was possible to directly appreciate the development of the teaching-learning process and it was possible to directly determine the participation of those involved within the context to be investigated

An elaborate questionnaire was used and applied, which allows detecting the behavior of the students, the same that helped to collect the primary information and at the same time allowed to know the criteria that the different students have about this topic. This is a structured and planned survey, as it is designed to collect information from those involved in the research problem.

The observation was direct since the investigation was carried out at the scene of the events, specifically to the teachers and students. To solve the questions, it was necessary to use the survey technique, for which an instrument was applied that was the structured questionnaire that served to collect information regarding the problem, it consists of 10 questions that contain the object of investigation and that serves to observe in what degree of problem is found and look for a prompt solution to the problem, it should also be noted that of these questions the analysis and interpretation of the results was carried out in order to finally reach the conclusions of the present work. Likewise, an observation sheet was prepared, which was applied to students and teachers, during class time, managing to determine the participation of those involved within the context to be investigated.

We worked with the entire sample, which is 169 students, to whom a survey on socioaffective strategies was applied that contains the categories of the research problem. To verify the hypothesis, the chi-square statistical test was used, which is a non-parametric 
or free distribution statistic that allows us to establish correspondence between observed and expected values, reaching up to the comparison of integer distributions, it is a test that allows global verification of the group of expected frequencies calculated from the hypothesis to be verified, between categorical contingency variables.

After having collected the data, they were transformed following the following procedures: The information will be cleaned of any contradiction, which is incomplete, not pertinent (Villanueva \& Navarro, 1997). It is the final stage that refers to the processing, tabulation, and interpretation of data, they will be carried out through the manual Tabulation system, analyzing survey by survey and analyzing response by response to group them in tables in which the statistical and percentage data are recorded, the same as They will be represented in graphs and later it will allow to obtain the conclusions and recommendations.

\section{Results}

The results obtained show that the state of mind in times of pandemic (Covid-19) directly influences the development of productive skills in the same way it is evident that a positive state of mind, a good attitude and having a good social and affective relationship helps the student to have a better collaborative learning since it improves interaction in the classroom causing greater interactivity between classmates and between the student and the teacher; Carrying out group activities helps and improves the development of productive skills since by sharing with the rest of their classmates, students feel more secure and calm when expressing themselves, and in this way obscure the problems caused by confinement due to the pandemic (Boakye, 2016).

After the analysis and interpretation of the results, we proceed to the verification of one of the proposed hypotheses, for the verification of the hypothesis we worked with $\&=$ 0.05. Showing that the final calculated value is greater than $\mathrm{X} 2$, which is why the null hypothesis (Ho) is rejected and the initial hypothesis (H1) is accepted. Socio-affective strategies impact on the development of productive skills and collaborative learning in times of pandemic in students.

Table 1

Chi square test

\begin{tabular}{ccccc}
\hline $\mathbf{O}$ & $\mathbf{E}$ & $\mathbf{O}-\mathbf{E}$ & $(\mathbf{O}-\mathbf{E})^{2}$ & $(\mathbf{O}-\mathbf{E})^{2} / \mathbf{E}$ \\
\hline 65 & 44,00 & 21 & 441 & 10,02 \\
54 & 50,00 & 4 & 16 & 0,32 \\
50 & 75,00 & -25 & 625 & 8,33 \\
\hline
\end{tabular}


Table 1

Chi square test (continued)

\begin{tabular}{llccc}
\hline $\mathbf{O}$ & $\mathbf{E}$ & $\mathbf{O}-\mathbf{E}$ & $(\mathbf{O}-\mathbf{E})^{\mathbf{2}}$ & $(\mathbf{O}-\mathbf{E})^{\mathbf{2}} / \mathbf{E}$ \\
\hline 45 & 44,00 & 1 & 1 & 0,02 \\
52 & 50,00 & 2 & 4 & 0,08 \\
72 & 75,00 & -3 & 9 & 0,12 \\
38 & 44,00 & -6 & 36 & 0,82 \\
54 & 50,00 & 4 & 16 & 0,32 \\
77 & 75,00 & 2 & 4 & 0,05 \\
28 & 44,00 & -16 & 256 & 5,82 \\
40 & 50,00 & -10 & 100 & 2,00 \\
101 & 75,00 & 26 & 676 & 9,01
\end{tabular}

Source: Carvajal (2006)

According to the graph and the results obtained from the proposed regions, the final value calculated is greater than $\mathrm{X} 2$, the null hypothesis (Ho) is rejected and the initial hypothesis (H1) is accepted, which says: Socio-affective strategies have an impact on the development of productive skills in students.

For everybody it is clear that nowadays education is different, but there are still some aspects, attitudes, and monotonous activities within education, making the acquisition of a second language something boring and undesirable. There are many possibilities to change this, to convert learning in something dynamic, something that marks student, and something that motivates them to freely express, using a language other than their native language. Therefore, these socio-affective activities guide will support teachers in order to improve the development of the productive skills to have a better teaching-learning process.

This research is based on strategic activities directly aimed at students of the third year of high school, which will help to enhance the acquisition of knowledge in a more practical and emotional way, taking into account the feelings of every student to be evaluated not only a quantitative but also in a qualitative way.

When carrying out an exhaustive search of the research works, it has been possible to verify the importance and relevance that these investigations have on the present project that is being carried out, mentions the development of a deep understanding of the productive skills, the which are a fundamental part of the learning framework, especially in students who need these skills to achieve a better understanding of the language and develop it in a better way, for which Muin and Aswati (2019) in his project entitled: 
"Strategies Methodology And Its Influence On The Development Of Productive Skills (Speaking And Writing) "concludes that: To promote the development of productive skills in the English language, it is necessary and convenient to use appropriate methodological strategies according to the level of learning.

Through the proper use of methodological strategies, a good result is obtained in the development of productive skills in the English language. The course teacher must change teaching methodologies that allow the development of productive English language skills. Similarly Wong (2018) "collaborative Learning and Its Influence on Productive Skills (oral and written)" concludes that: Productive skills (speaking and writing) are partially developed in most students, since the application of collaborative learning is limited. Working groups are formed on certain occasions within the classroom, this causes students to work individually.

Most of the students do not assume roles within the work groups since they are applied in certain situations, this produces the disorientation of activities. These criteria agree with the results obtained in the present research since it is evident that today education has varied especially in the learning of the English language in times of the COVID-19 pandemic, due to the need to immerse new learning strategies such as the socio-affective strategies that help the student to function better in collaborative learning, losing fear and thus achieve a better development of productive skills (oral and written) since these are essential for inter-learning.

For Indriana (2019) socio-affective strategies and the reduced development of productive skills in collaborative learning in times of pandemic is a problem that needs immediate solution, since if this problem is not adequately addressed, we would be faced with a major inconvenience within the teaching-learning process, which will have repercussions on the student's academic performance, directly affecting the development of productive skills, since by not being able to concentrate all their attention through the required socioaffective strategies, they will never achieve a comprehensive training that allows them to communicate in an oral or written form to be able to grow within the social environment to which they belong; therefore they would not be on par with a society that is more demanding and competitive day by day

Change, renew strategies and techniques that have been used in a monotonous way by teachers, it is thus, that by implementing these strategies and techniques it is intended to facilitate the learning of the English language in order to have better communication within and outside the classroom in a collaborative environment, since being able to communicate freely with others is a necessity that allows us to interact in order to have an improvement in the language, this improvement will help both the teacher and the student. To the teacher since he can use this as a guide to support material to improve the student's development both personally and emotionally when communicating, thus 
making interaction within the classroom easier. To the student since through these activities they will improve their fluency when expressing themselves either orally or in writing, feeling free to communicate expressing their ideas with society.

\section{Conclusions}

- The interest of this research work lies in raising the level of development of productive skills in collaborative learning and obtaining a better result using socio-affective strategies in students specifically in the pandemic caused by covid -19 , since the Confinement has limited students and teachers in the educational setting, formed a virtual barrier in collaborative learning. Concluding that by investigating existing pedagogical problems, solutions are provided that allow to raise the academic performance of students and provide society with students with the ability to solve problems and assume the reins of their own destiny Fandiño (2010) says, the non-use of socio-affective strategies permanently influences the inter-learning process, affecting the social and affective part not only of students but also of teachers, thus causing a low development of productive skills. The progress achieved by teachers during confinement due to the pandemic (covid-19) is not what was expected, since socio-affective strategies in the inter-learning process that help in the dynamism within the classroom, in order to enhance the development of productive skills in collaborative learning.

- The non-use of socio-affective strategies permanently influences the interlearning process, affecting the development of productive skills in students' development of productive skills by students, while the progress made by teachers in the area of English is not as expected, since socio-affective strategies in the inter-learning process that help in dynamism within the classroom, in order to enhance the development of productive skills in the English language.

- Likewise, various activities are framed that can be used as many times as necessary during the teaching-learning process since it can be acquired and applied in an easy, practical, and concise way because it is direct and adaptable to any type of change that is necessary to cover the pertinent needs. Urdiales and García (2004) Being a feasible contribution to communication and development of the same as it improves the opportunities to express themselves freely, providing opportunities for teachers and students to improve the learning of the English language within a social context. 


\section{References Bibliographical}

Boakye, N. (2016). The efficacy of socio-affective teaching strategies in a reading intervention: Students' views and opinions. Language Matters, 47(3), 393-414. https://doi.org/10.1080/10228195.2016.1226379

Fandiño, Y. (2010). Explicit Teaching of Socio-Affective Language Learning Strategies to Beginner EFL Students. Íkala, Revista de Lenguaje y Cultura.

Golkova, D., \& Hubackova, S. (2014). Productive Skills in Second Language Learning. Procedia - Social and Behavioral Sciences, 143(June), 477-481. https://doi.org/10.1016/j.sbspro.2014.07.520

Herrera, L., Medina, A. \& Naranjo, G. (2010). Tutoria de la investigación científica. Ambato: Graficas Corona.

Indriana, N. U. R. R. (2019). Socio-Affective Strategies Used by the Students to Improve Their English-Speaking Skill: A Case Study in Second Semester at Muhammadiyah. Jurnal Auladuna, 4(4), 1-14.

Liu, Y. (2020). Effects of metacognitive strategy training on chinese listening comprehension. Languages, 5(2), 1-22. https://doi.org/10.3390/languages5020021

Monereo, C., Catelló, M., Clariana, M., Palma, M. \& Lluisa, M. (2007). Estrategias de enseñanza y aprendizaje. (p. 130). Barcelona: Colofón, S.A.

Muin, A., \& Aswati, A. (2019). Effects of Socio-Affective Strategies on Students' SelfConfidence in Classroom Speaking Activities. Loquen: English Studies Journal, 12(2), 91. https://doi.org/10.32678/loquen.v12i2.2178

Mutia, H. (2020). The implementation of socio-affective strategy to improve students' speaking skill at the second-grade students.

Robiansyah, M. \& Rochmahwati, P. (2020). Socio-Affective Strategies Employed By. ELTALL (English Language Teaching, Applied Linguistics and Literature), 1(1), 917. https://jurnal.iainponorogo.ac.id/index.php/eltall

Rukmini, D., \& Saputri, L. A. D. E. (2017). The authentic assessment to measure students' English productive skills based on 2013 Curriculum. Indonesian Journal of Applied Linguistics, 7(2), 263-273. https://doi.org/10.17509/ijal.v7i2.8128

Sreena, S., \& Ilankumaran, M. (2018). Developing Productive Skills Through Receptive Skills - A Cognitive Approach. International Journal of Engineering \& Technology, 7(4.36), 669. https://doi.org/10.14419/ijet.v7i4.36.24220 
Urdiales, C. \& García, J. (2004). Los carriles de la expresión escrita. (p. 110). Madrid: Ediciones Akal, S.A.

Villanueva, M. L. \& Navarro, I. (1997). Los estilos de aprendizaje de lenguas. (pág. 210). Jaume: Castelló D’impressió S.L.

Wong, R. (2018). The Effect of Socio-affective Strategies on Students ${ }^{\text {ee }}$ Test Anxiety across Different Genders. Theory and Practice in Language Studies, 8(2), 177. https://doi.org/10.17507/tpls.0802.01

\section{Ciencia Digitzal}


El artículo que se publica es de exclusiva responsabilidad de los autores y no necesariamente reflejan el pensamiento de la Revista Conciencia Digital.

\section{Liencia}

El artículo queda en propiedad de la revista y, por tanto, su publicación parcial y/o total en otro medio tiene que ser autorizado por el director de la Revista Conciencia Digital.
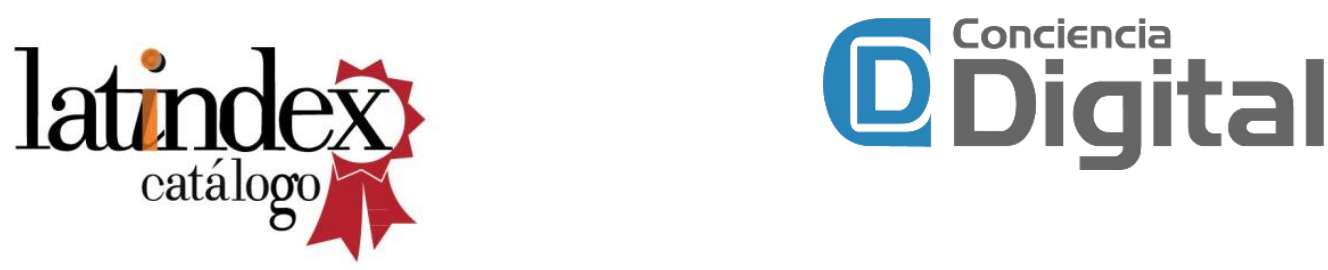

Indexaciones

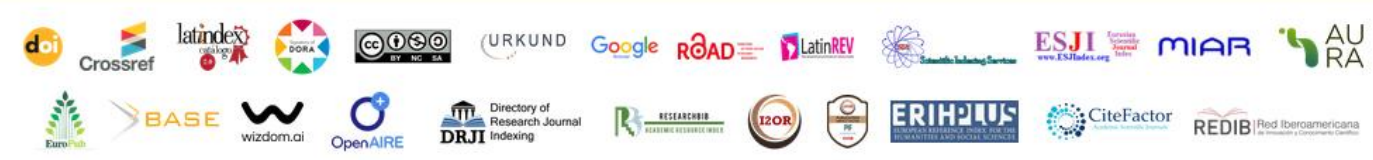

